\title{
PENGARUH BAWANG MERAH (ALLIUM CEPA, L.) TERHADAP PENURUNAN KADAR KOLESTEROL DARAH PADA PENDERITA HIPERLIPIDEMIA DI WILAYAH KERJA PUSKESMAS KARANGNONGKO KABUPATEN KLATEN
}

\author{
Agus Winarso, Youstiana Dwi Rusita, Bambang Yunianto \\ Kementerian Kesehatan Politeknik Kesehatan Surakarta Jurusan Jamu
}

\begin{abstract}
Cholesterol Blood, Red Onion (Allium Cepa, L.), Hyperlipidemia. Changes in lifestyle, diet and advances in technology may lead to a decline in physical activity in the community, resulting in the occurrence of energy imbalance. Hyperlipidemia was a condition to an increase in cholesterol and or triglyceride serum upper limit of normal. Onion (Allium cepa, L) contains quercetin in high enough levels can reduce total cholesterol. This study used a sample of onion powder capsules that aims to determine the effect of onion (Allium cepa, L.) to decrease blood cholesterol levels in patients with hyperlipidemia. This research is a pre-experimental design, wherein the treatment group were given capsules of onion (Allium cepa, L.) using a randomized experimental design pretest-Post test Group Design. This study uses the Shapiro Wilk normality test with the sample amounted to 31 people. Based on the results of non-parametric Wilcoxon statistical test showed that cholesterol levels before taking capsules red onion ranged between $226 \mathrm{mg} / \mathrm{dl}$ and $370 \mathrm{mg} / \mathrm{dl}$ with an average of $281.7 \mathrm{mg} / \mathrm{dl}$. While cholesterol levels after consuming capsules onion ranged between $129 \mathrm{mg} / \mathrm{dl}$ and 400 $\mathrm{mg} / \mathrm{dl}$ with an average of $273.7 \mathrm{mg} / \mathrm{dl}$. The value of $p=0.737(\alpha>0.05)$ means that there is not a statistically significant effect capsule onion powder to decrease cholesterol levels.
\end{abstract}

Keywords : Cholesterol Blood, Red Onion (Allium Cepa, L.), Hyperlipidemia

Abstrak: Kadar Kolesterol Darah, Bawang Merah (Allium cepa, L.), hiperlipidemia. Perubahan gaya hidup, pola makan dan kemajuan teknologi dapat menimbulkan terjadinya penurunan aktifitas fisik pada masyarakat sehingga mengakibatkan terjadinya ketidakseimbangan energi. Hiperlipidemia adalah suatu keadaan terjadinya peningkatan kolesterol dan/ atau trigliserida serum di atas batas normal. Bawang Merah (Allium cepa, L) memiliki kandungan quercetin dalam kadar yang cukup tinggi yang dapat menurunkan kadar kolesterol total. Penelitian ini menggunakan sampel kapsul serbuk bawang merah yang bertujuan untuk mengetahui pengaruh pemberian bawang merah (Allium cepa, L.) terhadap penurunan kadar kolesterol darah pada penderita hiperlipidemia. Jenis penelitian ini adalah praeksperiment, dimana kelompok perlakuan diberi kapsul bawang merah (Allium cepa, L.) dengan menggunakan rancangan eksperimental Pretest-Post test Group Design. Penelitian ini menggunakan uji normalitas dengan Shapiro Wilk dengan sampel berjumlah 31 orang. Berdasarkan hasil uji statistik non parametric Wilcoxon memperlihatkan bahwa kadar kolesterol sebelum mengkonsumsi kapsul bawang merah berkisar antara $226 \mathrm{mg} / \mathrm{dl}$ dan $370 \mathrm{mg} / \mathrm{dl}$ dengan rata-rata 281,7 mg/dl. Sedangkan kadar 
kolesterol setelah mengkonsumsi kapsul bawang merah berkisar antara $129 \mathrm{mg} / \mathrm{dl}$ dan $400 \mathrm{mg} / \mathrm{dl}$ dengan rata-rata $273,7 \mathrm{mg} / \mathrm{dl}$. Nilai $\mathrm{p}=0,737(\alpha>0,05)$ berarti tidak ada pengaruh yang bermakna secara statistik kapsul serbuk bawang merah terhadap penurunan kadar kolesterol.

Kata Kunci : Kadar Kolesterol Darah, Bawang Merah (Allium cepa, L.), Hiperlipidemia

\section{PENDAHULUAN}

Kemajuan teknologi dapat membuat manusia tidak perlu mengeluarkan banyak energi untuk beraktifitas. Perubahan gaya hidup, pola makan dan kemajuan teknologi dapat menimbulkan terjadinya penurunan aktifitas fisik pada masyarakat sehingga mengakibatkan terjadinya ketidakseimbangan energi. Hiperlipidemia adalah suatu keadaan terjadinya peningkatan kolesterol dan/ atau trigliserida serum di atasbatas normal (Price, 2006). Peningkatan kolesterol serum yang terjadi, terutama mencerminkan peningkatan kolesterolLDL. LDL (Low Density Lipoprotein) merupakan lipoprotein yang memiliki kandungan kolesterol tertinggi dibandingkan lipoprotein lainnya (Price, 2006). Bawang merah mengandung quercetin dalam kadar yang tinggi, saponin, isorhamnetin dan glikosida (Fattoruso, 2002). Pada penelitian lain dikatakan bahwa quercetin dapat menurunkan kadar kolesterol total dan kadar kolesterol-LDL, dengan cara menghambat sekresi apolipoprotein $B$, dan menurunkan aktivitas MTP (microsomal triaglyceride transfer protein) yang memiliki peran dalam pembentukan lipoprotein dengan mengatalisa perpindahan lipid ke molekul Apo B (Casaschi, 2002).

\section{METODE PENELITIAN}

Penelitian ini adalah studi komparasi dengan menggunakan rancangan praeksperimen (pre-experimental design). Desain yang digunakan dalam penelitian ini adalah one group pretest posttest design. Dalam rancangan ini tidak ada kelompok pembanding (kontrol), tetapi paling tidak sudah dilakukan observasi pertama (pretest). Populasi pada penelitian ini adalah semua penderita kolesterol tinggi di Wilayah kerja Puskesmas Karangnongko Kabupaten Klaten. Sampel penelitian ini yaitu menggunakan teknik quota sampling. Jumlah sampel dalam penelitian ini diperoleh dengan cara memberikan kuota setiap desa diambil 5 orang penderita hipelripidemia dikalikan jumlah desa yang ada (11 desa) sehingga mendapatkan 55 orang, selanjutnya sampel disaring (diskreening) dengan pemeriksaan kadar kolesterol (pre test). Selanjutnya orang-orang dengan kadar kolesterol di atas $200 \mathrm{mg} / \mathrm{dl}$, dipilih sebagai sampel untuk mendapat perlakuan. Setelah screening (pre test) didapatkan 31 orang dengan kadar koletserol di atas $200 \mathrm{mgd} / \mathrm{l}$ yang bertindak sebagai sampel. Variabel dalam penelitian ini yaitu variabel bebas adalah bawang merah variabel terikat adalah kadar kolesterol darah. 
Instrument yang digunakan dalam penelitian ini adalah lembar ceklist yang berisi tentang identitas responden dan kadar kolesterol sebelum perlakuan, kapsul bawang merah, data kadar kolesterol responden setelah perlakuan dan kolesterol test. Prosedur pelaksanaan penelitian menyiapkan alat dan bahan, mengukuran kadar kolesterol sebelum perlakuan dengan alat Kolesterol Test, memberikan kapsul bawang merah dengan dosis per hari sebanyak 6 gram selama 15 hari pada responden yang kadar kolesterol tingg, memberikan Komunikasi Informasi Edukasi (KIE) tentang nutrisi dan aturan pakai untuk kapsul bawang merah, mengecek kadar kolesterol pada hari ke 16, mencatat kadar kolesterol sesudah perlakuan. Data yang didapat diuji normalitas yang digunakan dalam penelitian ini adalah uji Shapiro-Wilk. Data berdistribusi tidak normal, maka uji yang digunakan adalah uji non parametrik. Uji non parametrik yang sesuai dengan penelitian ini adalah uji Wilcoxon. Dilakukan dengan Statistical Product and Service Solution (SPSS) versi 16

\section{HASIL PENELITIAN}

Penentuan Bahan yaitu Bawang merah (Allium cepa L.) dengan berat 50 $\mathrm{kg}$ dikeringkan dan dioven kemudian diserbuk. Identifikasi serbuk bawang merah (Allium cepa L.)

Identifikasi makroskopis serbuk bawang merah dilakukan dengan uji organoleptis. Hasil organoleptis dapat dilihat pada tabel berikut ini

\section{Tabel 1}

\begin{tabular}{|ll}
\multicolumn{1}{c}{ Hasil Identifikasi Serbuk Bawang } \\
Merah
\end{tabular}

Identifikasi mikroskopis serbuk bawang merah. Fragmen pengenal menunjukkan adanya sel epidermis yang berbentuk segi empat, parenkim dengan sel berisi tetesan minyak, kristal kalsium oksalat bentuk prisma dan trakea dengan penebalan tangga.

Skrining fitokimia serbuk bawang merah. Hasil skrining fitokimia serbuk bawang merah (Allium cepa L.) dapat dilihat pada tabel di bawah ini :

Tabel 2

\section{Hasil Skrining Fitokimia Serbuk Bawang Merah}

\begin{tabular}{|c|c|c|c|}
\hline Identifikasi & Prosedur & Hasil & Kesimpulan \\
\hline Tanin & $\begin{array}{l}\text { Serbuk, } \\
\text { Aquades, } \\
\text { gelatin } 1 \%\end{array}$ & - & $\begin{array}{l}\text { Tidak } \\
\text { Mengandung } \\
\text { Tanin }\end{array}$ \\
\hline \multirow[t]{2}{*}{ Alkaloid } & $\begin{array}{l}\text { Serbuk, } \\
1,5 \mathrm{ml} \\
\text { HCL } 2 \% \text {, } \\
\text { reagen } \\
\text { dragendrof }\end{array}$ & + & $\begin{array}{l}\text { Mengandung } \\
\text { Alkanoid }\end{array}$ \\
\hline & $\begin{array}{l}\text { Serbuk, } \\
1,5 \mathrm{ml} \\
\text { HCL } 2 \%, \\
\text { reagen } \\
\text { mayer }\end{array}$ & + & $\begin{array}{l}\text { Mengandung } \\
\text { Alkaloid }\end{array}$ \\
\hline Kuinon & $\begin{array}{l}\text { Serbuk, } \\
\text { aquades, } \\
\text { KOH 5\% }\end{array}$ & + & $\begin{array}{l}\text { Mengandung } \\
\text { Alkanoid }\end{array}$ \\
\hline $\begin{array}{l}\text { Seskuiterpen } \\
\text { dan } \\
\text { monoterpen }\end{array}$ & $\begin{array}{l}\text { Serbuk, } \\
\text { eter, } \\
\text { kocok } \\
\text { kemudian } \\
\text { ambil } \\
\text { lapisan } \\
\text { eter } \\
\text { diuapkan, } \\
\text { tetesi } \\
\text { vanilin } \\
10 \% \\
\text { dalam } \\
\text { H2SO4(p) }\end{array}$ & + & $\begin{array}{l}\text { Mengandung } \\
\text { seskuiterpen } \\
\text { dan } \\
\text { monoterpen }\end{array}$ \\
\hline Saponin & $\begin{array}{l}\text { Serbuk, } \\
\text { HCL } \\
\text { encer } \\
\text { kocok }\end{array}$ & - & $\begin{array}{l}\text { Tidak } \\
\text { Mengandung } \\
\text { Saponin }\end{array}$ \\
\hline Flavanoid & $\begin{array}{l}\text { Serbuk, } \\
\text { serbuk }\end{array}$ & + & $\begin{array}{l}\text { Mengandung } \\
\text { Flavanoid }\end{array}$ \\
\hline
\end{tabular}


$\mathrm{Mg}, \mathrm{HCL}$

$2 \mathrm{~N}$,

panaskan,

amil

alkohol,

kocok

Penetapan kadar air serbuk bawang merah.

\section{Tabel 3}

Hasil Penetapan Kadar Air Dalam Serbuk Bawang Merah

\begin{tabular}{cc}
\hline Berat serbuk & Kadar air $(\% \mathrm{~b} / \mathrm{b})$ \\
\hline 2,022 & $3,96 \%$ \\
2,024 & $3,46 \%$ \\
2,088 & $3,60 \%$ \\
\hline Rata-rata & $3,67 \%$ \\
\hline
\end{tabular}

Hasil penetapan kadar air serbuk bawang merah didapatkan rata-rata sebesar 3,67 \%. Hasil dari penetapan kadar air memenuhi persyaratan yang ditetapkan yaitu kurang dari 10\% (Anonim 1979).

Perhitungan dosis serbuk bawang merah. Dosis pada tikus harus dikonversikan terlebih dahulu. Dosis yang digunakan pada manusia untuk serbuk bawang merah adalah 5,6 gram tetapi pada penelitian ini menggunakan 6 gram.

Pembuatan kapsul serbuk bawang merah. Penelitian ini membuat sekitar 3.150 kapsul. Bawang merah yang sudah di oven dengan suhu $60 \mathrm{C}$ selama 10 jam kemudian diblender dan ditimbang dengan berat 6 gram dan dimasukkan ke dalam cangkang kapsul ukuran 00. Serbuk bawang merah yang sudah dikapsul kemudian dimasukkan kedalam botol dan beri silica gel agar kapsul tersebut tidak lembab. Kemudian baru diberi label dan disegel.

\section{PEMBAHASAN}

Berdasarkan karakteristik usia, responden paling banyak usia 46-55 tahun sebanyak 14 orang $(45,2 \%)$. Responden paling sedikit berusia 2530 tahun $(9,7 \%)$. Semakin bertambanya umur seseorang, resiko memiliki kolesterol tinggi pun akan semakin meningkat. Kolesterol yang ada di pembuluh darah semakin lama semakin menebal, semakin bertambah usia maka penebalan plak pada pembuluh darah yang terjadi pun akan semakin meningkat, pada pria umunya kadar kolesterol terus meningkat setelah berumur lebih dari 45 tahun. Sementara pada wanita akan naik saat menopause atau di atas 55 tahun. Pada usia yang semakin lanjut plak kolesterol yang menumpuk pada pembuluh darah akan semakin menebal. (Mulyanto, 2012).

Berdasarkan karakteristik jenis kelamin, prosentase tertinggi perempuan sebanyak 28 orang $(90,3 \%)$, sedangkan laki-laki sebanyak 3 orang $(9,7 \%)$. Dalam hasil penelitian Wiyono dkk (2004) perempuan lebih beresiko menderita kolesterol tinggi dibandingkang laki-laki. Hal ini diperkirakan adanya perbedaan perilaku dan cara hidup. Dilihat dari segi gender, wanita sebagai ibu rumah tangga yang bertanggung jawab terhadap pengadaan konsumsi makanan di rumah sehingga lebih terpapar terhadap makanan, salah satunya makanan tinggi kolesterol atau berlemak. Disamping itu aktifitas fisik lebih ringan dibandingkan laki-laki.

Berdasarkan jumlah responden terbanyak yaitu pada jenis kolesterol yang berbahaya yaitu dengan kadar kolesterol > 240 sebanyak 31 orang yang berarti $100 \%$ dari semua responden. Hal ini terjadi karena untuk rata-rata responden berumur 
lebih dari 45 tahun dimana resiko kenaikan kadar kolesterol jauh lebih besar.

Pada usia yang semakin lanjut plak kolesterol yang menumpuk pada pembuluh darah akan semakin menebal. (Mulyanto, 2012). Pada responden yang sudah mengkonsumsi kapsul bawang merah untuk antikolesterol jumlah responden terbanyak yaitu kadar kolesterol dengan jenis berbahaya sebanyak 21 orang, sedangkan untuk kadar kolesterol jenis perbatasan sebanyak 4 orang dan kadar kolesterol yang normal sebanyak 6 orang. Hal tersebut menunjukkan bahwa kapsul bawang merah mempunyai pengaruh terhadap penurunan kadar kolesterol pada kategori kadar kolesterol normal, kadar kolesterol perbatasan dan kadar kolesterol berbahaya.

Berdasarkan hasil uji statistik non parametric Wilcoxon memperlihatkan bahwa kadar kolesterol sebelum mengkonsumsi kapsul bawang merah berkisar antara $226 \mathrm{mg} / \mathrm{dl}$ dan $370 \mathrm{mg} / \mathrm{dl}$ dengan rata-rata $281,7 \mathrm{mg} / \mathrm{dl}$. Sedangkan kadar kolesterol setelah mengkonsumsi kapsul bawang merah berkisar antara 129 $\mathrm{mg} / \mathrm{dl}$ dan $400 \mathrm{mg} / \mathrm{dl}$ dengan rata-rata $273,7 \mathrm{mg} /$ dl. Nilai $p=0,737$ yang berarti lebih dari $\alpha=0,05$. Kapsul bawang merah dapat menurunkan kadar kolesterol responden sebesar $8 \mathrm{mg} / \mathrm{dl}$. Hasil uji statistik tersebut dapat diketahui bahwa kapsul bawang merah tidak mempunyai pengaruh yang bermakna secara statistik terhadap penurunan kadar kolesterol dalam darah.

Hasil pemeriksaan darah pasca perlakuan menunjukkan bahwa, hanya sebagian kecil responden yang kadar kolesterol darahnya turun secara bermakna, sebagian besar responden kadar kolesterolnya masih tinggi dan dalam kategori berbahaya. Hal ini sesuai dengan teori yang dikemukakan Wahab (2013), bahwa pengendalian kadar kolesterol yang tinggi ini sangat dipengaruhi oleh diet serta konsumsi obat antikolesterol baik yang berupa obat kimia, maupun konsumsi obatobat herbal. Walaupun responden dalam penelitian ini sudah mengonsumsi obat, terutama obat antikolesterol golongan herbal (kapsul bawang merah), tetapi peneliti tidak dapat mengawasi diet dari responden. Sehingga hasil dari penelitian ini, walaupun mengonsumsi obat antikolesterol, tetapi hasil pemerikasaan pasca perlakuan, sebagian besar kadar kolesterol dalam darah responden masih tinggi. Hasil wawancara dengan responden yang kadar kholesterolnya masih tetap tinggi setelah perlakuan, sebagian besar mereka mengatakan bahwa, mereka tidak mengendalikan makan untuk makanan yang mengandung kolesterol tinggi. Hasil wawancara yang disampaikan secara polos oleh mereka, bahwa diantara mereka yang tetap tinggi kadar kolesterolnya, karena pada saat penelitian kebetulan sedang musim buah durian, dan mereka penggemar buah durian, dan tetap mengonsumsi walaupun kadar kolesterolnya tinggi.

\section{KESIMPULAN DAN SARAN}

Kadar kolesterol penderita hiperlipidemia sebelum mengkonsumsi kapsul bawang merah berkisar antara 226 $\mathrm{mg} / \mathrm{dl}$ dan $370 \mathrm{mg} / \mathrm{dl}$ dengan rata-rata $281,7 \mathrm{mg} / \mathrm{dl}$. Kadar kolesterol penderita hiperlipidemia setelah mengkonsumsi kapsul bawang merah berkisar antara 129 $\mathrm{mg} / \mathrm{dl}$ dan $400 \mathrm{mg} / \mathrm{dl}$ dengan rata-rata $273,7 \mathrm{mg} / \mathrm{dl}$. Tidak Ada pengaruh yang bermakna secara statistik kapsul bawang merah terhadap penurunan kadar 
kolesterol yaitu dengan $\mathrm{p}=0,737 \quad(\alpha>$ 0,05). Penderita Hiperlipidemia disarankan untuk mengkonsumsi bawang merah secara teratur sehingga dapat menurunkan kadar kolesterol dalam darah. Diharapkan dapat menggunakan data hasil penelitian ini sebagai dasar melakukan penelitian lebih lanjut dengan mengembangkan variabel yang belum diteliti pada penelitian ini, serta melakukan pengembangan metode penelitiannya.

\section{DAFTAR RUJUKAN}

Casaschi Adele, Qi wang, Ka'ohimanu Dang, Alison Richards, and Andre Theriault, 2002. Intestinal Apolipoprotein B Secretion Is Inhibited by the Flavonoid Quercetin: Potential Role of Microsomal Triglycerida Transfer Protein and Diacylglycerol Acyltransferase. Lipids. Vol. 37, No. 7

Piparo E, Scheib H, Frei N, Williamson G, Grigorov M, Nestle C., 2008, Flavonoids for Controlling Starch Digestion: Structural Requirements for Inhibiting Human $\alpha$-Amylase. J Med Chem. Vol. 51, No. 12.

Price Sylvia A, Lorraine M. Wilson, 2006. Patofisiologi Konsep Klinis Proses-Proses Penyakit, edisi 6. Jakarta : Penerbit Buku Kedokteran EGC

Sheperd J. 2001. The Role Of The Exogenous Pathway In Hypercholesterolaemia. European Heart J3 Supl E:2-5.

Soebroto, Linda, 2010. Hubungan antara Kadar LDL Kolesterol pada Penderita Stroke di RSUD Dr. Moewardi Surakarta. (Skripsi). UNS : Fakultas Kedokteran.
Wahab Abdul, 2013. Pengantar Riset Bidang Kesehatan, Kebidanan, dan Keperawatan. Penerbit : Kaukaba Dirgantara, Jakarta. 